\title{
Water Quality Index of river Thamirabarani at Papanasam (upper\&lower dam) region, Tamilnadu, India
}

\author{
S.Rajesh, NVN.Nampoothiri, S.Vanitha
}

\begin{abstract}
This study is done to evaluate water quality of the Thamirabarani river, by using Water Quality Index method. The water quality index of the river water was done, by analyzing the physical and chemical parameters of water samples taken at seven locations in Jan 2017 to March 2017, along the through flow path of the river. The analysis results were compared with maximum permissible limit values recommended by WHO and BIS for drinking, irrigation and aquatic life. The water quality for Dinking was assessed utilizing the WQI technique. The computed WQI values in this study are found to be between 55.65 to 23.3(for drinking), 47.1 to 14.4 (for Irrigation) and 61.2 to 15.4(for Aquatic life).The results are indicates that, for the stretch of Tamirabarani where study was conducted, the water is suited for irrigation.
\end{abstract}

Keywords: Drinking water, Physicochemical Characteristics, Pollution, Water Quality Index, Water Quality indicators, Thamirabarani river.

\section{INTRODUCTION}

In current decades, India has been encountering fast financial development, populace increment and urbanization. These procedures have stressed the deficiency of water assets in Tamilnadu, especially in the desolate districts of Southern Tamilnadu. Water is a significant normal asset of earth and assumes an imperative job in our life. Surface water and Groundwater are the key sources of water. The water quality of Thamirabarani River, an important domestic and potable water source of Southern Tamilnadu.

The waterway Thamirabarani is referenced as the Porunai nathi in Tamil beautiful writing. It gets thankfulness and is alluded to as the eminent one in Sanskrit news coverage references to which are as old as that of the Puranas and Legends. The river is the most important perennial river among the 33 rivers of Tamilnadu. The river Thamirabarani originates from the peak of Periyapothigai hill in the Western Ghats over Papanasam in the Ambasamudram Taluk. The river traverses Tirunelveli and Thoothukudi districts before

Revised Manuscript Received on December 30, 2019.

* Correspondence Author

S.Rajesh*, Department of Civil Engineering, Kalasalingam Academy srajesh@klu.ac.in,rajeshkvm88@gmail.com

Dr.NVN.Nampoothiri, Department of Civil Engineering, Kalasalingam Academy Research \& Higher Education, Krishnankoil,, India. Email: nnpciv@klu.ac.in.

Dr.S.Vanitha, Department of Civil Engineering, Kalasalingam Academy Research \& Higher Education, Krishnankoil,, India. Email: svanitha@klu.ac.in. Research \& Higher Education, Krishnankoil,, India. Email:

joining the Gulf of Mannar. The total catchment area is 4500 $\mathrm{km}^{2}$.

It runs for about $120 \mathrm{~km}$ traversing for about $80 \mathrm{~km}$ including $24 \mathrm{~km}$ in hills in Tirunelveli district and for about $40 \mathrm{~km}$ in Tuticorin district. It forms a delta in Punnakayal village before outfalling into Bay of Bengal. The area of the delta is 140.93 sq.km. It has about 50 large and small islands, the largest with an area of 20 sq. km and smallest with an area of 0.1 sq. $\mathrm{km}$.

The river Thamirabarani basin lies within $08^{0} 8^{\prime}$ and $09^{\circ} 23^{\prime}$ $\mathrm{N}$ latitude and $77^{\circ} 09^{\prime}$ and $77^{\circ} 54^{\prime} \mathrm{E}$ longitude. The river basin of the Tirunelveli district includes Shenkottai, Tenkasi, Kadayanallur, Sankarankovil (Part), Veerakeralampudur, Ambasamudram, Nanguneri (Part), Tirunelveli and Palayamkottai taluks. In the Thoothukudi district Srivaikuntam and Tiruchendur Taluks (Part), are in the river basin.

Thamirabarani river basin receives rainfall through the early showers of southwest monsoon and of the later rains of the northeast monsoon. The yearly precipitation is $814.8 \mathrm{~mm}$ and is all around conveyed.. The dams and anicuts constructed on Thamirabarani and Manimuthar rivers provide both agriculture and power generation benefits. The Thamirabarani River affords perennial irrigation to a fairly large area on which two crops are normally raised. A few tanks and wells structure some portion of the other wellspring of water system.(G.Venkatesan et al., 2012;Krishankumar et al., 2013;Mopin -kani et al.,2014).

The current study has been conceded out to estimate the water quality characteristics of Thamirabarani river in the Papanasam (upper and lower dam) region by using water quality index which helps the common man to know the value of water.

Understanding water quality requires quantitative knowledge of physical, chemical and biological characteristics and comparing their levels with standards to support for different uses including potable and irrigation use (ICAR Bulletin, No.71, 2014). The ICAR Research Bulletin identifies the important water quality parameters to be analyzed for irrigation water.

The quality of water depends on the concentration of different constituents in it. The concentrations of constituents depend on its sources of origin and interventions through living or dead organisms in the way of its stream and there for inherently depend on the location of water. So in this study, the locations of water sampling sites are taken with a GPS and the latitude and longitude noted. 


\section{STUdy AREA}

\section{A. Water Samples Sites}

The water samples from Thamirabarani river were collected from seven stations. The sampling station could be considered as "source point". The seven stations were selected considering their human activities and Hydro power generation. The location details of the sampling stations are shown in Table 1. The samples were collected from all source point at $11 \mathrm{am}$.

Table-1: Water Sampling Site Locations

\begin{tabular}{|c|c|c|}
\hline Sampling Stations & Latitude & Longitude \\
\hline Kariyar dam & $8^{0} 38^{\prime} 14^{\prime \prime N}$ & $77^{0} 17^{\prime} 41^{\prime \prime} \mathrm{E}$ \\
\hline $\begin{array}{l}\text { Sorimuthu Ayyanar } \\
\text { Temple }\end{array}$ & $8^{0} 39^{\prime} 18.94 ” \mathrm{~N}$ & $77^{0} 20^{\prime} 12.75^{\prime \prime} \mathrm{E}$ \\
\hline $\begin{array}{l}\text { Kariyar \& Servalar } \\
\text { Junction Bridge }\end{array}$ & $8^{0} 40^{\prime} 51.09^{\prime \prime} \mathrm{N}$ & $77^{0} 20^{\prime} 47.03^{\prime \prime} \mathrm{E}$ \\
\hline $\begin{array}{l}\text { Agasthiyar falls and } \\
\text { three sources point }\end{array}$ & $8^{0} 42^{\prime} 15.02 ’ \mathrm{~N}$ & $77^{0} 21^{\prime} 49.40{ }^{\prime \prime} \mathrm{E}$ \\
\hline $\begin{array}{l}\text { Papanasam-1(Lower } \\
\text { dam), }\end{array}$ & $8^{0} 42^{\prime} 30^{\prime \prime} \mathrm{N}$ & $77^{0} 22^{\prime} 5^{\prime \prime} \mathrm{E}$ \\
\hline $\begin{array}{l}\text { Papanasam-2(Lower } \\
\text { dam) }\end{array}$ & $8^{0} 42^{\prime} 33^{\prime \prime} \mathrm{N}$ & $77^{0} 22^{\prime} 7^{\prime \prime} \mathrm{E}$ \\
\hline $\begin{array}{l}\text { Papanasam-3(Lower } \\
\text { dam) }\end{array}$ & $8^{0} 42^{\prime} 48^{\prime \prime} \mathrm{N}$ & $77^{0} 22^{\prime} 11^{\prime \prime} \mathrm{E}$ \\
\hline
\end{tabular}

\section{Methodology AND ChARACTERISTICS ANALYSIS}

\section{A. Analytical Procedure}

Surface water status is controlled by the more terrible of natural and compound status. The physico-chemical analyses and biological tests were performed using standard technical methods.

Water quality requirements for different uses of water are scientifically termed as criteria and the permissible level of contaminants in water for different uses without any negative impact on environment and society are termed as Standards. These are legally enforced levels set up by a governmental or any international agency that have been arrived at after consideration of water quality criteria and the economic, social and political consequences of possible regulatory action (ICAR Bulletin, No.7,2014).

\section{B. Water Quality Index (WQI):}

A water quality index relates a gathering of water quality parameters to a general scale and combines then into a single number in unity with a chosen method of computation. The favored utilization of WQI is to asses water quality patterns for executive purpose, although, it is not meant for an absolute measure of the level of pollution or the real water quality. The water quality index was evaluated by considering nine important physico-chemical parameters (Table 3,4\&5) using ICMR (WHO) along with BIS standards by the following formula.

$$
\boldsymbol{W Q I}=\Sigma W_{n} * Q_{n}
$$

Where, $\mathrm{W}_{\mathrm{n}}$-Unit Weight(parameter weightage),

$$
\begin{aligned}
& \mathrm{Q}_{n} \text {-Quality Rating } \\
& Q_{n}=100 * \frac{\left(V_{n}-V_{i 0}\right)}{\left(S_{n}-V_{i 0}\right)}
\end{aligned}
$$

Where,

parameter.

$\mathrm{Q}^{-}$Quality Rating for the $\mathrm{n}^{\text {th }}$ water quality

$\mathrm{V}_{\mathrm{n}^{-}}$Observed value of the $\mathrm{n}^{\text {th }}$ parameter for the given sample.

$\mathrm{S}_{\mathrm{n}}$ - Standard Permissible value of the $\mathrm{n}^{\text {th }}$ parameter.

$\mathrm{V}_{\mathrm{i} 0}$-Ideal value of $\mathrm{n}^{\text {th }}$ parameter in the pure water

*All the Ideal values $\left(\mathrm{V}_{\mathrm{i} 0}\right)$ are taken as zero for

drinking water

(except for $\mathrm{pH}=7$ and dissolved oxygen $=14.6$

$\mathrm{mg} / \mathrm{l})$

$\boldsymbol{W}_{n}=\frac{w_{n}}{\sum w_{n}}$

Where, $\mathrm{W}_{\mathrm{n}}$-Unit Weight of the Water quality parameter

$\mathrm{w}_{\mathrm{n}}$-weight of each parameter,

n-number of parameters

\section{RESULTS AND DISCUSSIONS}

- pH Value: The $\mathrm{pH}$ value of a water source is measure of its acidity or alkalinity. The $\mathrm{pH}$ level is a measure of the action of the hydrogen molecule, on the grounds that the hydrogen development is a decent portrayal of the causticity or alkalinity of the water. $\mathrm{pH}$ ranges from 6 and 9 along the basin at various distances the permissible limit in 8.5 and desirable limit is 7 for drinking water. The $\mathrm{pH}$ tends to slightly decrease along the course of the river.

- TDS: Total dissolved solids in water are a measure of all organic and in-organic substances contained in it. The Primary application of TDS is in the study of water quality for streams, lakes and river although TDS is not considered as a primary pollutant. The Primary source for TDS in receiving waters are agricultural \& residential runoff, discharge from industrial or sewage treatment plants or leaching of soil contamination. Usually higher concentration of TDS is not a health hazard. The TDS standard range from 128 to $768 \mathrm{mg} / \mathrm{l}$. The TDS values are in the suggested range.

- Hardness: Hardness is the presence of minerals in water, typically Sulphates of Calcium and Magnesium. Hardness Standards were recorded between 1-60 mg/l. The level of hardness is taken as under:

Soft

Moderately soft

Slightly hard

Moderately hard

$$
\begin{aligned}
& : 0-50 \mathrm{mg} / 1 \\
& : 50-100 \mathrm{mg} / 1 \\
& : 100-150 \mathrm{mg} / 1 \\
& : 150-250 \mathrm{mg} / 1 .
\end{aligned}
$$

Therefore, water quality of surface water indicating towards Soft and Moderately soft.

- Chloride: The chloride ion is formed when the element chlorine (a halogen) gains an electron to form an anion. $\mathrm{Cl}^{-}$. The salts of hydrochloric contain chloride ions and can also be called chlorides. As per IS 10500 , the permissible limit for the presence of chloride content in water is $250 \mathrm{mg} / \mathrm{l}$. but this could be extended up to $1000 \mathrm{mg} / \mathrm{l}$. hence, the water present in the whole district has chloride value in its safe limits. Concentration of chloride was found to range from 7 to $78 \mathrm{mg} / \mathrm{L}$. 
- Sodium: The variation of sodium in each station is different. Its higher concentrations could be detected by its taste being salty. Sodium can be released naturally into water through mineral deposits in ground water, surface water. The Value of Sodium ranged between 0.01 to $14 \mathrm{mg} / \mathrm{l}$.

- Calcium: Calcium, as the $\mathrm{Ca}^{2+}$ particle, is one of the major inorganic cations, or positive particles, in salt water and fresh water. The calcium is usually required for drinking water in the range of 75 to 200 $\mathrm{mg} / \mathrm{L}$.

- Magnesium: Magnesium is a fundamental component for the growth and development of human beings. The estimation of magnesium went somewhere in the range of 2.2 and $12 \mathrm{mg} / \mathrm{L}$ in the of waterway streaming regions

- Potassium: Potassium is an vital component and is present in all animal and plant tissues. The Value of Potassium ranged between 0.01 to $0.78 \mathrm{mg} / \mathrm{L}$.

- Dissolved oxygen (DO): The value of DO varied from 1.2 to $2.7 \mathrm{mg} / \mathrm{L}$. The DO in surface waters of the streaming way regions is underneath the allowable furthest reaches of $6 \mathrm{mg} / \mathrm{L}$ during every one of the seasons.

\section{- Bio-Chemical Oxygen Demand (BOD):} Concentration of BOD was found 0.75 to 1.42 $\mathrm{mg} / \mathrm{L}$.It represents aquatic living organism of water and impacts the rate of substance and organic responses.

The calculated of WQI(Drinking, Irrigation, Aquatic) of 7-stations are given in Tables 3-5. The water quality index and its rating for drinking, irrigation and aquatic life purposes are given in Table 6. WQI of surface water of flowing path areas of Thamirabarani River, status of water quality at different sites are given in Table 7. The WQI is a useful method to assess the water quality of surface water.

Table- 6: Water Quality Index Scale for Drinking , Irrigation\& Aquatic life

\begin{tabular}{|c|c|c|}
\hline S.No & Range & Quality \\
\hline 1 & $0-25$ & Excellent \\
\hline 2 & $26-45$ & Good \\
\hline 3 & $51-75$ & Very Poor \\
\hline 4 & $76-100$ & $\begin{array}{c}\text { Unsuitable for } \\
\text { Drinking,Irrigation, } \\
\text { Aquatic life }\end{array}$ \\
\hline 5 & 100 and above \\
\hline
\end{tabular}

\section{CONCLUSION}

In this study, the water quality of the Thamirabarani River and its suitability of drinking, irrigation, and aquatic life were evaluated. To evaluate water quality of the Thamirabarani River, 7 source points were determined and 11 water quality parameters were selected for monitoring and analysis. Water quality parameters $\mathrm{pH}, \mathrm{EC}, \mathrm{TDS}, \mathrm{HCO}, \mathrm{Cl}$,
$\mathrm{SO} 4, \mathrm{Mg}, \mathrm{Ca}, \mathrm{K}, \mathrm{DO}, \mathrm{BOD}, \mathrm{COD}$, and $\mathrm{Na}$ were used to calculate WQI values to evaluate the river water quality. The results indicate that the river water varied, to drinking, irrigation and aquatic life. The computed WQI values are between 23.3 to 52.65 for drinking, 14.4 to 47.1 for Irrigation, and 15.4 to 61.2 for Aquatic life. The water quality index classification shows that table 7.WQI values and Classes are shown on the satellite image in Figure 1. The size of the circle is proportional to the WQI value. As the size increases water quality decreases for a specific purpose. It can be visualized that the WQI is higher in locations Kariayar dam(1) and Papanasam3(6). This can be attributed to pollution due to tourism and bathing/cleaning effects. On other locations, the Tamiarabarani is in a relatively "Good" quality class. Hence it is recommended that the "Good" and "Excellent" quality is preserved along the Tamirabarani by suitable conservation and pollution prevention options. Other places of moderate and serve pollution may be required to be treated and further pollution prevented. The water nature of surface water, particularly stream water, must be checked occasionally. It is basic practice to decide the nature of waterway waters during the summer and winter seasons.

\section{REFERENCES}

1. APHA, "Standard Methods for Water and Wastewater Analysis", 20th ed., American Public Health Association, Washington, D.C. 1998

2. A.R.K. Kulandaivel, P. E. Kumar, V. Perumal and P. N. Magudeswaran 2009. "Water Quality Index of River Cauvery At Erode Region, Tamilnadu, India", Nature Environment and Pollution Technology, Volume 8,No:2, PP.343-346

3. Brown, R.M., McClelland, Dewinger, R.A. and Togen, R.C. 1970. "A Water Quality Index - Do We dare? Water Sewage Works", 11: 339-343.

4. Damir Tomas and Mirjana Curlin 2017. "Assessing the surface water status in Pannonian ecoregion by the water quality index model", Ecological Indicators, 79, PP.182-190.

5. G.B.Chaturvedi, B. B. Mishra and D. D. Tewari 2008. "Water Quality Index of Ground waters Near Industrial Areas of Balrampur, U.P.", Nature Environment and Pollution Technology, Volume1,No:2, PP.331-335.

6. Gopalaswami, P.M., Kumar, P.E. and Kulandivelu, A.R., 2003. "Study on the quality ofwater in the Bhavani river", Asian J. Chem., 15(1): 306-310.

7. Horton, R.K. 1965. “An index number system for rating water quality”. J. Water Poll. Control Fed., 37: 300-305.

8. Jie wang, Houqi Liu and Paul K.S.Lam 2017. "Multivariate statistical evaluation of dissolved trace elements and a water quality assessment in the middle reaches of Huaihe River Anhui,China", Science of Total Environment, STOTEN-21801; No of Pages 11,Press Article.

9. Magudeswaran, P.N. and Ramachandran, T. 2007. "Water Quality Index of River Noyyal at Tiruppur, Tamilnadu, India", Nature Environment and Pollution Technology, 6(1): 51-54.

10.Magudeswaran, P.N, Kamalakkannan, N. and Ramachandran, T. 2006. "Water Quality Index of Rivers Siruvani, Bhavani and Noyyal using alternate Water Quality Index". Poll. Res., 25(3): 519-523.

11.Mausumi Raychaudhuri, S. Raychaudhuri, S. K. Jena, Ashwani Kumar and R. C. Srivastava (2014). "WQI to monitor water quality for irrigation and potable use". ICAR Research Bulletin, No.71, 2014: 10-16.

12.Sehnaz Sener and Erhan Sener 2017. "Evaluation of water quality using Water Quality Index method and GIS in Aksu River", Science of Total Environment,584-585, PP.131-144

13. Shweta Tyagi, Bhavtosh Sharma, Prashant Singh, Rajendra Dobhal 2013. "Water Quality Assessment in terms of Water Quality Index", American Journal of Water resources,2013, Vol.1,No.3,34-38

14.S.Sowmiya Lakshmi,S.Rajesh and Premkumar R ,2018, "Removal of Organic Pollutants From Textile Dye Wastewater By Advanced Oxidation Process", International Journal of Civil Engineering \& Technology, (IJCIET), Volume 9,Issue 4,April 2008,:PP 452 - 461. 


\section{AUTHORS PROFILE}

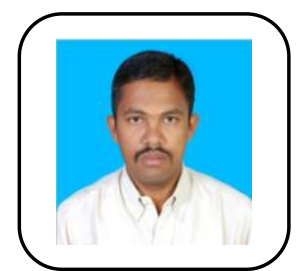

Er.S.Rajesh Completed B.E(Civil) degree from GCE, Tirunelveli in 2009 and M.E(Environmental) degree from ACCET,Karakudi in 2013. He is working as Asst professor in KARE , Krishnankoil and Research scholar in KARE.His research area is Envionmental Engineerring..He is having 7 years Academic Experience and 10 years Industry consultancy Experience. He is Chartered Engineer \& Valuer in India. He is Professional member of the IOV, IEI and PE. He has published more than 10 SCOPUS indexed Journal and Conference in and around India.

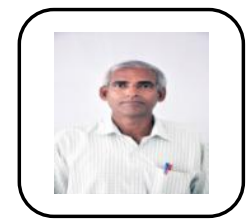

Second Author completed his $\mathrm{PhD}$ in IIT Bombay.His research area is remote sensing and GIS. $\mathrm{He}$ is former professor in KARE. He has 25 years academic experience and 13 years industry experience. He has published more than 50 nos Journals and Conferences.He is life member of remote sensing. Geo-informatic society of india and Indian society of

Third Author completed B.E(Civil) degree from GCE, Triunelveli,M.E(Environmental) degree from AKCE, Krishnankoil and $\mathrm{PhD}$ from KARE, Krishanankoil. She is working as Associate professor in KARE. Her Research Area is Environmental Engineering. She has published more than 15 no's of Indian and International SCOPUS indexed Journal. 
International Journal of Innovative Technology and Exploring Engineering (IJITEE) ISSN: 2278-3075, Volume-9 Issue-2S2, December 2019

Table-2: Physico - Chemical recommended Standards for Drinking Water, Irrigation water and Aquatic life by BIS

\begin{tabular}{|c|c|c|c|c|c|c|c|c|}
\hline S.No & Parameter & $\begin{array}{l}\text { Standard range } \\
\text { Drinking water }\end{array}$ & $\begin{array}{l}\text { Weightage }\left(w_{n}\right) \\
\text { drinking water }\end{array}$ & $\begin{array}{l}\text { Standard range } \\
\text { Irrigation water }\end{array}$ & $\begin{array}{c}\text { Weightage }\left(\mathbf{w}_{\mathbf{n}}\right) \\
\text { Irrigation } \\
\text { water } \\
\end{array}$ & $\begin{array}{c}\text { Standard } \\
\text { range } \\
\text { aquatic life }\end{array}$ & $\begin{array}{c}\text { Weightage }\left(w_{n}\right) \\
\text { aquatic life }\end{array}$ & $\begin{array}{c}\text { Methods of } \\
\text { Analysis }\end{array}$ \\
\hline 1 & $\mathrm{pH}$ & $6.5-8.5$ & 6 & $6.5-8.5$ & 4 & $6.5-8.5$ & 6 & $\begin{array}{l}\text { Electrometric } \\
\text { Method }\end{array}$ \\
\hline 2 & $\begin{array}{c}\text { Electrical } \\
\text { Conductivity }\end{array}$ & $50-300$ & 4 & $0.7-3.0$ & 4 & $20-50$ & 4 & $\begin{array}{l}\text { Nephelometric } \\
\text { Method }\end{array}$ \\
\hline 3 & $\begin{array}{l}\text { Total Dissolved } \\
\text { Solids }(\mathrm{mg} / \mathrm{l})\end{array}$ & $500-2000$ & 4 & $500-1000$ & 2 & $500-1200$ & 4 & $\begin{array}{l}\text { Gravimetric } \\
\text { Method }\end{array}$ \\
\hline 4 & $\begin{array}{c}\text { Total Hardness as } \\
\mathrm{CaCo}_{3}(\mathrm{mg} / \mathrm{l})\end{array}$ & $200-600$ & 2 & - & - & - & - & EDTA Method \\
\hline 5 & Magnesium(mg/l) & $30-100$ & 2 & $1-5$ & 2 & - & - & AAS Method \\
\hline 6 & Sodium(mg/l) & $50-200$ & 3 & - & - & - & - & AAS Method \\
\hline 7 & Potassium(mg/l) & $0-.3$ & 2 & $.1-2$ & 1 & - & - & AAS Method \\
\hline 8 & Calcium(mg/l) & $75-200$ & 2 & $5-20$ & 1 & - & - & AAS Method \\
\hline 9 & $\begin{array}{c}\text { Dissolved } \\
\text { Oxygen(mg/l) }\end{array}$ & 6 & 4 & - & - & $4-14.6$ & 7 & $\begin{array}{l}\text { Winklers } \\
\text { Titrimetric Method }\end{array}$ \\
\hline 10 & Chloride $(\mathrm{mg} / \mathrm{l})$ & $250-1000$ & 3 & $5-30$ & 1 & $250-600$ & 3 & Mohr Method \\
\hline 11 & $\begin{array}{c}\text { Biological Oxygen } \\
\text { Demand(mg/l) }\end{array}$ & 5 & 4 & & & - & - & $\begin{array}{l}\text { Oxygen difference } \\
\text { method }\end{array}$ \\
\hline 12 & $\mathrm{SAR}(\mathrm{mg} / \mathrm{l})$ & - & - & $5-15$ & 4 & $5-26$ & 4 & AAS Method \\
\hline 13 & Carbonate $(\mathrm{mg} / \mathrm{l})$ & - & - & $0-.1$ & 1 & - & - & EDTA Method \\
\hline 14 & Bicarbonate $(\mathrm{mg} / \mathrm{l})$ & - & - & $8-10$ & 1 & - & - & EDTA Method \\
\hline 15 & Sulphate $(\mathrm{mg} / \mathrm{l})$ & - & - & $5-20$ & 1 & - & - & $\begin{array}{l}\text { Gravimetric } \\
\text { Method }\end{array}$ \\
\hline & $\sum w_{n}$ & & 36 & & 22 & & 32 & \\
\hline
\end{tabular}


Water Quality Index of river Thamirabarani at Papanasam (upper\&lower dam) region, Tamilnadu, India

Table-3: Physico-Chemical Characteristics for Drinking water analysis of Thamirabarani @ Papanasam upper and lower dam

\begin{tabular}{|c|c|c|c|c|c|c|c|c|}
\hline S.No & Parameters & $\begin{array}{c}\text { Karaiyar Dam } \\
@ 0 \mathrm{KM} \\
\end{array}$ & $\begin{array}{c}\text { Sorimuthuayyanar } \\
\text { Temple @3.07KM }\end{array}$ & $\begin{array}{c}\text { Bridge } \\
@ 6.8 \mathrm{KM} \\
\end{array}$ & $\begin{array}{c}\text { Agasthiyar } \\
\text { Falls } \\
@ 10.35 \mathrm{KM} \\
\end{array}$ & $\begin{array}{c}\text { Papanasam } 1 \\
\text { @ 11.14KM } \\
\end{array}$ & $\begin{array}{c}\text { Papanasam } 2 \\
\text { @ 11.24KM } \\
\end{array}$ & $\begin{array}{c}\text { Papanasam } 3 @ \\
11.87 \mathrm{KM}\end{array}$ \\
\hline 1 & $\mathrm{pH}$ & 8.16 & 7.6 & 6.75 & 7.6 & 6.48 & 6.1 & 7.35 \\
\hline 2 & $\mathrm{EC}$ & 110 & 80 & 120 & 60 & 20 & 20 & 50 \\
\hline 3 & Chlorides as $\mathrm{Cl}$ in $(\mathrm{mg} / \mathrm{l})$ & 7.1 & 14.2 & 17.75 & 10.65 & 35.5 & 42.6 & 78.1 \\
\hline 4 & $\begin{array}{c}\text { Total Dissolved Solids in } \\
(\mathrm{mg} / \mathrm{l})\end{array}$ & 704 & 512 & 768 & 384 & 128 & 128 & 32 \\
\hline 5 & $\begin{array}{c}\text { Total Hardness as } \mathrm{CaCO}_{3} \\
\text { in }(\mathrm{mg} / \mathrm{l})\end{array}$ & 60 & 60 & 60 & 40 & 12 & 1 & 24 \\
\hline 6 & Magnesium as Mg in (mg/l) & 7.2 & 2.4 & 4.8 & 3.6 & 12 & 9.6 & 10.15 \\
\hline 7 & Sodium as $\mathrm{Na}$ in $(\mathrm{mg} / \mathrm{l})$ & 2.3 & 0.1 & 6.9 & 0.01 & 0.01 & 14.95 & 20.5 \\
\hline 8 & Potassium as $\mathrm{K}$ in $(\mathrm{mg} / \mathrm{l})$ & 0.67 & 0.01 & 0.01 & 0.01 & 0.78 & 0.78 & 0.02 \\
\hline 9 & Calcium as $\mathrm{Ca}$ in $(\mathrm{mg} / \mathrm{l})$ & 4.8 & 4.8 & 4.8 & 3.2 & 9.6 & 0.4 & 15.2 \\
\hline 10 & DO in $(\mathrm{mg} / \mathrm{l})$ & 1.62 & 1.54 & 2.17 & 1.69 & 1.3 & 1.2 & 1.7 \\
\hline 11 & BOD in $(\mathrm{mg} / \mathrm{l})$ & 1.34 & 0.75 & 1.42 & 1.3 & 1.06 & 0.96 & 1.2 \\
\hline 12 & WQI & 52.65 & 26.6 & 27.09 & 26.67 & 44.20 & 48.02 & 23.22 \\
\hline
\end{tabular}


International Journal of Innovative Technology and Exploring Engineering (IJITEE) ISSN: 2278-3075, Volume-9 Issue-2S2, December 2019

\begin{tabular}{|c|c|c|c|c|c|c|c|c|}
\hline S.No & Parameters & $\begin{array}{c}\text { Karaiyar Dam } \\
@ 0 K M\end{array}$ & $\begin{array}{c}\text { Sorimuthuayyanar } \\
\text { Temple @3.07KM }\end{array}$ & $\begin{array}{c}\text { Bridge } \\
@ 6.8 \mathrm{KM} \\
\end{array}$ & $\begin{array}{c}\text { Agasthiyar } \\
\text { Falls } \\
\text { @ 10.35KM } \\
\end{array}$ & $\begin{array}{c}\text { Papanasam } 1 \\
\text { @ 11.14KM } \\
\end{array}$ & $\begin{array}{c}\text { Papanasam } 2 \\
\text { @ } 11.24 \mathrm{KM} \\
\end{array}$ & $\begin{array}{c}\text { Papanasam } 3 \text { @ } \\
11.87 \mathrm{KM}\end{array}$ \\
\hline 1 & $\mathrm{pH}$ & 8.16 & 7.6 & 6.75 & 7.6 & 6.48 & 6.1 & 7.35 \\
\hline 2 & $\mathrm{EC}$ & 0.11 & 0.08 & 0.12 & 0.6 & 0.2 & 20 & 50 \\
\hline 3 & Total Dissolved Solids & 704 & 512 & 768 & 384 & 128 & 42.6 & 78.1 \\
\hline 4 & SAR & 3 & 2 & 3 & 4 & 5 & 128 & 32 \\
\hline 5 & $\mathrm{CO}_{3}-{ }_{2}$ & $0 . .01$ & 0.01 & 0.01 & 0.01 & 0.01 & 1 & 24 \\
\hline 6 & $\mathrm{HCO}_{3-}^{-}$ & 0.7 & 0.5 & 0.8 & 0.4 & 1.3 & 9.6 & 10.15 \\
\hline 7 & Chlorides as $\mathrm{Cl}$ & 0.2 & 0.4 & 0.5 & 0.3 & 1 & 14.95 & 20.5 \\
\hline 8 & $\mathrm{SO}_{4}$ & 0.01 & 0.01 & 0.1 & 0.01 & 0.01 & 0.78 & 0.02 \\
\hline 9 & Magnesium as Mg & 0.6 & 0.2 & 0.4 & 0.3 & 1 & 0.4 & 15.2 \\
\hline 10 & Pottassium as $\mathrm{K}$ & 0.67 & 0.01 & 0.01 & 0.01 & 0.78 & 1.2 & 1.7 \\
\hline 11 & Calcium as $\mathrm{Ca}$ & 0.24 & 4.8 & 4.8 & 3.2 & 9.6 & 0.96 & 1.2 \\
\hline 12 & WQI & 47.71 & 22.5 & 14.40 & 22.26 & 22.32 & 48.00 & 23.23 \\
\hline
\end{tabular}

Table-5: Physico-Chemical Characteristics for Aquatic life analysis of Thamirabarani @ 
Water Quality Index of river Thamirabarani at Papanasam (upper\&lower dam) region, Tamilnadu, India

\begin{tabular}{|c|c|c|c|c|c|c|c|c|}
\hline S.No & Parameters & $\begin{array}{c}\text { Karaiyar Dam } \\
@ 0 K M\end{array}$ & $\begin{array}{c}\text { Sorimuthuayyanar } \\
\text { Temple @3.07KM }\end{array}$ & $\begin{array}{c}\text { Bridge } \\
@ 6.8 \mathrm{KM} \\
\end{array}$ & $\begin{array}{c}\text { Agasthiyar } \\
\text { Falls } \\
\text { @10.35KM } \\
\end{array}$ & $\begin{array}{c}\text { Papanasam } 1 \\
\text { @ 11.14KM }\end{array}$ & $\begin{array}{c}\text { Papanasam } 2 \\
@ 11.24 \mathrm{KM} \\
\end{array}$ & $\begin{array}{c}\text { Papanasam } 3 \text { @ } \\
11.87 \mathrm{KM}\end{array}$ \\
\hline 1 & $\mathrm{pH}$ & 8.16 & 7.6 & 6.75 & 7.6 & 6.48 & 6.1 & 7.35 \\
\hline 2 & Ec & 110 & 80 & 120 & 60 & 20 & 20 & 50 \\
\hline 3 & Chlorides as $\mathrm{Cl}$ & 7.1 & 14.2 & 17.75 & 10.65 & 35.5 & 42.6 & 78.1 \\
\hline 4 & Total Dissolved Solids & 704 & 512 & 768 & 384 & 128 & 128 & 32 \\
\hline 5 & SAR & 3 & 2 & 3 & 4 & 5 & 5.3 & 4.5 \\
\hline 6 & DO & 1.62 & 1.54 & 2.17 & 1.69 & 1.3 & 1.2 & 1.7 \\
\hline 7 & BOD & 1.34 & 0.75 & 1.42 & 1.3 & 1.06 & 0.96 & 1.2 \\
\hline 8 & WQI & 61.23 & 35.8 & 1.42 & 29.58 & 33.12 & 15.40 & 21.9 \\
\hline
\end{tabular}


International Journal of Innovative Technology and Exploring Engineering (IJITEE) ISSN: 2278-3075, Volume-9 Issue-2S2, December 2019

\begin{tabular}{|c|c|c|c|c|c|}
\hline S.No & Place & Distance in Km & $\begin{array}{c}\text { WQI for Drinking } \\
\text { purpose }\end{array}$ & $\begin{array}{c}\text { WQI for Irrigation } \\
\text { purpose }\end{array}$ & $\begin{array}{c}\text { WQI for Aquatic } \\
\text { life }\end{array}$ \\
\hline 1 & Karaiyar Dam & 0 & $52.65(\mathrm{MP})$ & $47.1(\mathrm{MP})$ & $61.2(\mathrm{MP})$ \\
\hline 2 & Sorimuthuayyanar Temple & 3.07 & $26.6(\mathrm{G})$ & $22.5(\mathrm{E})$ & $35.8(\mathrm{G})$ \\
\hline 3 & Bridge & 6.81 & $27.1(\mathrm{G})$ & $14.4(\mathrm{E})$ & $55.5(\mathrm{MP})$ \\
\hline 4 & Agasthiyar Falls & 10.35 & $26.67(\mathrm{G})$ & $22.2(\mathrm{E})$ & $29.6(\mathrm{G})$ \\
\hline 5 & Papanasam 1 & 11.14 & $44.2(\mathrm{G})$ & $34.1 \mathrm{E})$ & $34.61(\mathrm{G})$ \\
\hline 6 & Papanasam 2 & 11.24 & $48.02(\mathrm{MP})$ & $15.4(\mathrm{E})$ \\
\hline 7 & Papanasam 3 & 11.87 & $23.3(\mathrm{E})$ & $17.92(\mathrm{E})$ & $21.9(\mathrm{E})$ \\
\hline
\end{tabular}

E=Excellent, $\mathrm{G}=\mathrm{Good}, \mathrm{MP}=$ Moderately Polluted

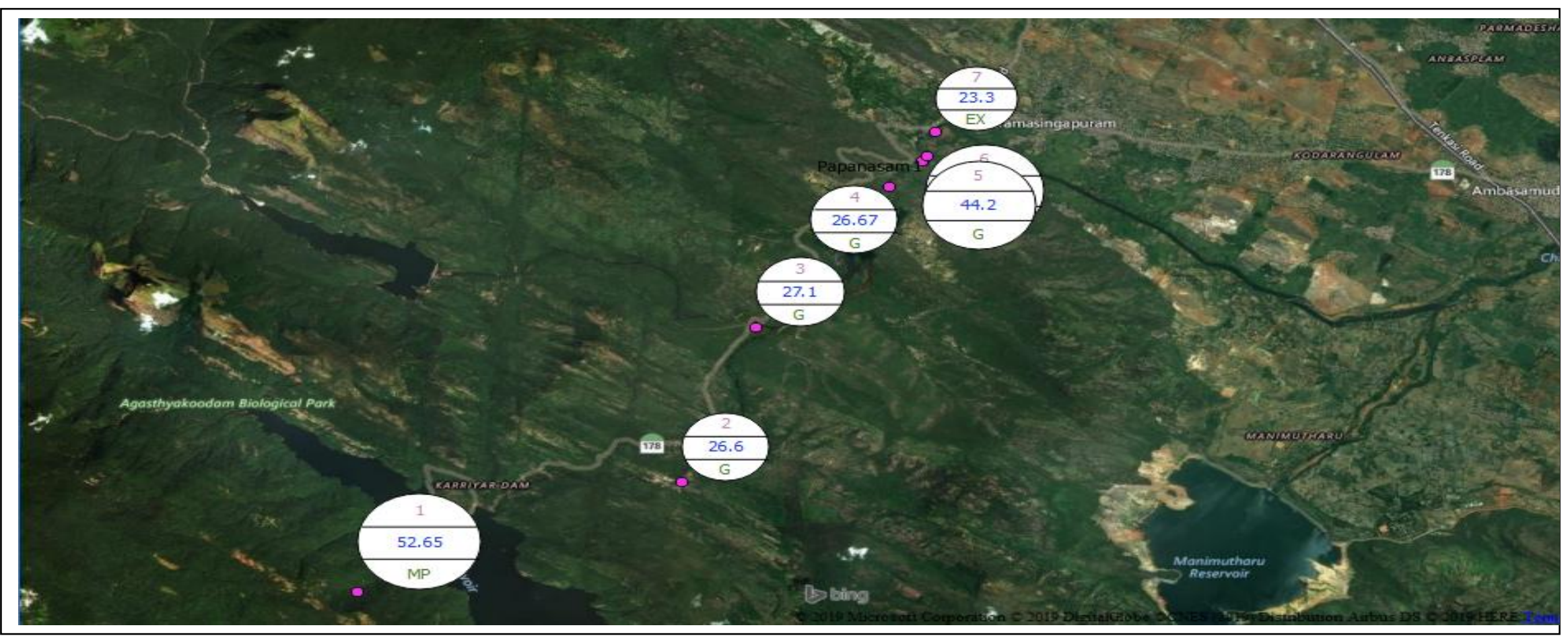

Fig 1: Tamirabarani River-Papanasam WQI image

Retrieval Number: B10241292S219/2019@BEIESP DOI: 10.35940/ijitee.B1024.1292S219
Published By:

Blue Eyes Intelligence Engineering

\& Sciences Pulboration

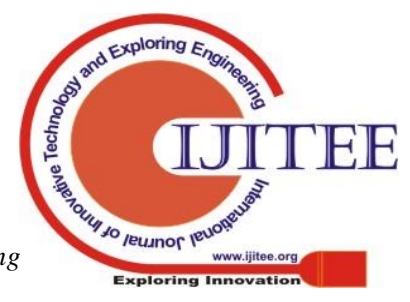

